\title{
A Rare Case of Multiple Talon Cusps in Three Siblings
}

\author{
Alireza SARRAF-SHIRAZI ${ }^{1}$ \\ Minoo REZAIEFAR ${ }^{2}$ \\ Maryam FORGHANI ${ }^{2}$
}

\author{
${ }^{1}$ Department of Pediatric Dentistry, Mashhad, University of Medical Sciences, Mashhad, Iran \\ ${ }^{2}$ Dental Research Center of Mashhad, University of Medical Sciences, Mashhad, Iran
}

\begin{abstract}
Talon cusp is an uncommon anomaly, whose etiology may be disturbances in the morphodifferentiation stage. Dens in dente is also a rare anomaly that is challenging in clinic as it may cause pulp necrosis or periapical lesions due to the communication with the oral cavity. This article reports multiple talon cusps on permanent maxillary and mandibular incisors and molars in 3 siblings. A 9-year-old boy presented with structures like nodules, shaped as cylindrical cones with a sharp point or a raindrop with deep developmental fissures on the palatal aspect of the maxillary central incisors, lingual aspect of the mandibular central incisors and labial aspect of both mandibular first molars. The buccal surface of the maxillary right central incisor was also affected. Some of them exhibited dens in dente. His 15 -yearold sister had prominent talon cusps on the palatal surface of maxillary central incisors and buccal surface of the mandibular first molars and mandibular left second molar. His 7-year-old brother had only one trace talon on the maxillary left central incisor. No syndrome was identified in the patients. In conclusion, genetic inheritance may be a causative factor in talon cusp.
\end{abstract}

Key Words: case report, talon cusp, sibling, dens in dente.

\section{INTRODUCTION}

Talon cusp is a rare entity in which a prominent wisplike structure originates from the cervical area of lingual or labial surfaces of the anterior teeth, occurring lingually with the most frequency (1). Mitchell was the first to recognize this anomaly in 1892 (2), which was later named talon by Ripa and Mellor due to its resemblance to an eagle's talon (3). It is most often seen the in permanent dentition, predominantly in the lateral maxillary incisor followed by the central maxillary incisor and maxillary canine $(1,4,5)$. Both males and females can be affected, with the former being more involved $(4,5)$.

Hattab et al. (4) classified talon cusps as: type I (talon), a morphologically well-delineated additional cusp that extends at least $50 \%$ of the inciso-cervical length of the tooth; type II, (semitalon), a morphologically welldefined additional cusp that extends $25-50 \%$ of the tooth length; and type III (trace talon), an enlarged or prominent cingulum, which occupies less than $25 \%$ of the distance from the cementoenamel junction to the incisal edge (4). Talon cusp can be accompanied by syndromes such as
Berardinelli-Seip (6), Mohr, Rubinstein and Taybi, Ellisvan Creveld, Sturge-Weber and incontinentia pigmenti achromians (7). The co-occurrence of talon cusp and other dental anomalies such as dens in dente and tooth germination has also reported $(8,9)$.

Dens in dente is a rare dental developmental anomaly with a frequency of about $0.04-10 \%$ of the population (10). It may be seen in the primary or permanent dentition (11), and occurs most often in the maxillary lateral incisor, followed by the maxillary central incisor (12). Oehlers (13) classified dens in dente based on its extension and communication with periapical or periodontal tissues as: invagination not extending over the CEJ; invagination entering the root either communicating or not with the pulp, and resembling a blind sac; and a form that usually does not have any communication with the pulp and has its own apical opening.

The aim of the present study was to report a complicated case of a boy with several developmental anomalies along with his two siblings, who presented talon cusps. This is thought to be the first report of the occurrence of multiple talon cusps in three siblings.

Correspondence: Dr. Alireza Sarraf-Shirazi, Postal Address: Pediatric Dentistry Department, Faculty of Dentistry, Mashhad, University of Medical Sciences, Mashhad, Iran. Tel: +98-511-8829525. Fax:+98-511-8829500. e-mail: Sarrafa@mums.ac.ir 


\section{CASE REPORT}

A 9-year-old boy was referred to the Department of Pediatric Dentistry of Mashhad Dental School. His medical history was uneventful. Oral hygiene was poor with multiple carious lesions. The chief complaint was the presence of a fistula with a history of 7-8 months on the buccal aspect of the maxillary left central incisor. The tooth had undergone an emergency treatment and the access cavity was sealed with a temporary filling material. There were structures like nodules, shaped as cylindrical cones with a sharp point or a raindrop, with deep developmental fissures on the palatal aspect of both maxillary central incisors. The buccal surface of the maxillary right central incisor was also affected (Fig.
1). Hence, talons were found on both labial and lingual surfaces of this tooth. Same structures were found on the lingual surface of mandibular central incisors and the labial surface of both mandibular first molars (Fig. 2). Radiographs showed dens in dente in the maxillary central incisors and left lateral incisor (Fig. 3). Periapical radiolucency was observed in the maxillary left incisor. Oral examination of his parents was not contributory, but his two siblings presented similar structures.

His 15-year-old sister had prominent talon cusps on the palatal surface of the maxillary central incisors and buccal surface of the mandibular first molars and left second molar (Fig. 4). His 7-year-old brother had only one trace talon on the maxillary left central incisor (Fig. 5), but he still had several unerupted teeth. Due to
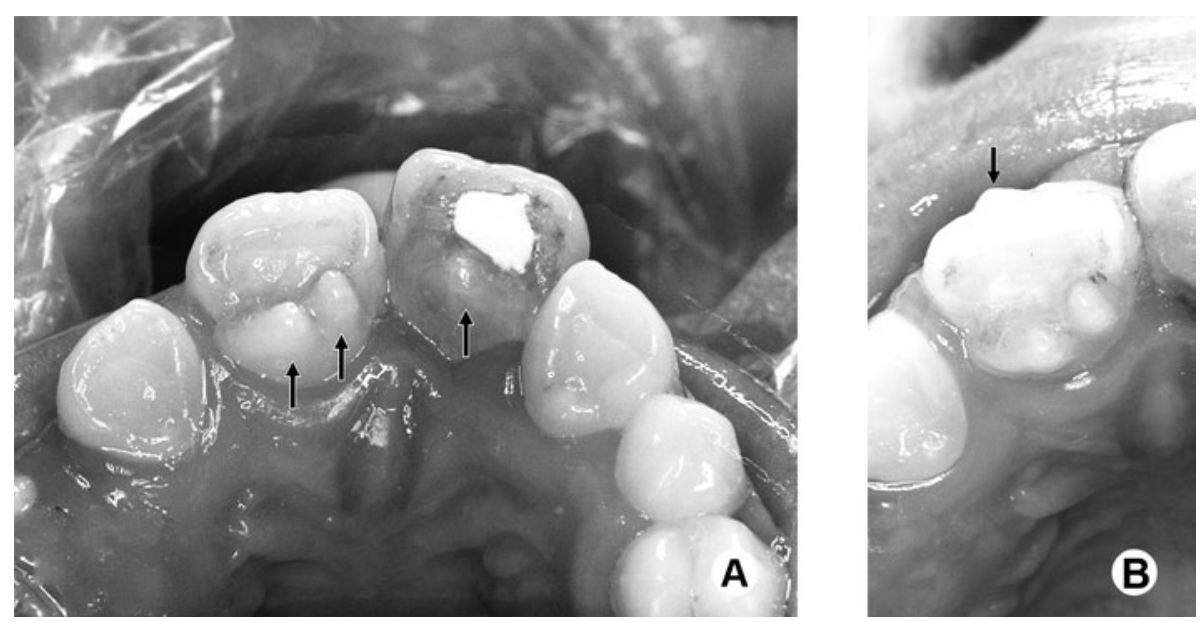

Figure 1. Intraoral clinical images. A: Talon cusps on the palatal surfaces of both maxillary central incisors. B: Incisal view of the maxillary right central incisor showing a buccal talon cusp (Case 1).
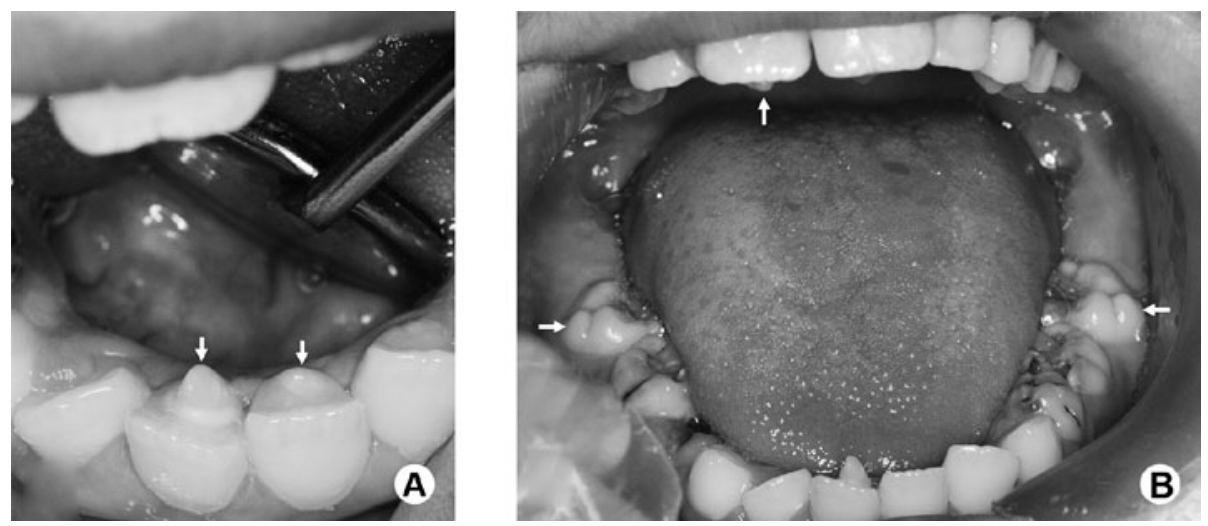

Figure 2. Intraoral clinical images. A: Talon cusps on lingual surfaces of both mandibular central incisors. B: Talon cusps on both mandibular first molars. Note the prominent talon cusp on maxillary right central incisor (Case 1). 
multiple teeth with carious lesions and pulp necrosis, all siblings were referred to the Departments of Endodontics and Pediatric Dentistry for appropriate endodontic, restorative and preventive treatments.

\section{DISCUSSION}

The accessory cusp-like structure, talon cusp, originates from disturbances in the morphodifferentiation stage of tooth development, as does any other anomaly in the size or shape of the tooth (14). The real cause of this condition is still unknown, but genetic and environmental factors are thought to be involved in the etiology. Sporadic occurrence of this abnormality is not uncommon $(1,7)$.

Dens in dente results from the invagination of the affected tooth crown before the mineralization $(10,15)$. It is usually detected in routine radiographs. Dealing with a dens in dente is challenging in clinic as it may cause pulp necrosis or periapical lesions due to the communication with the oral cavity and influx of

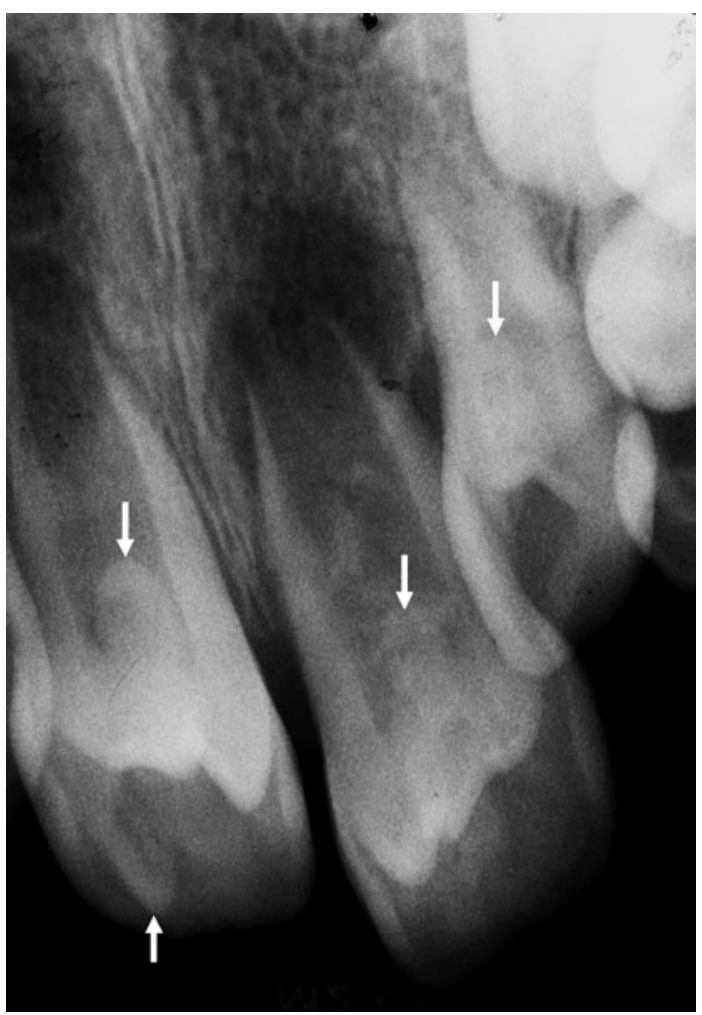

Figure 3. Periapical radiograph of maxillary incisors. Dens in dente of both maxillary central incisors and left lateral incisor is evident. Due to the access cavity preparation, the dens in dente of the left central incisor is not clear. Note the radiopacity of buccal talon cusp on right central incisor (Case 1). the irritants to the pulp $(10,12)$.

There are very few reports of multiple siblings affected by talon cusps. Meon reported talon cusps in a 10 -year-old boy and his 12-year-old sister (16). Segura and Jimenez-Rubio reported 2 cases of talon cusp affecting consanguineous first cousins, and affirmed that family involvement and the association of the talon cusp with other dental abnormalities suggest genetics as a probable major causative factor (17). Hattab et al. (18) and Solanki et al. (6) reported siblings with talon cusps
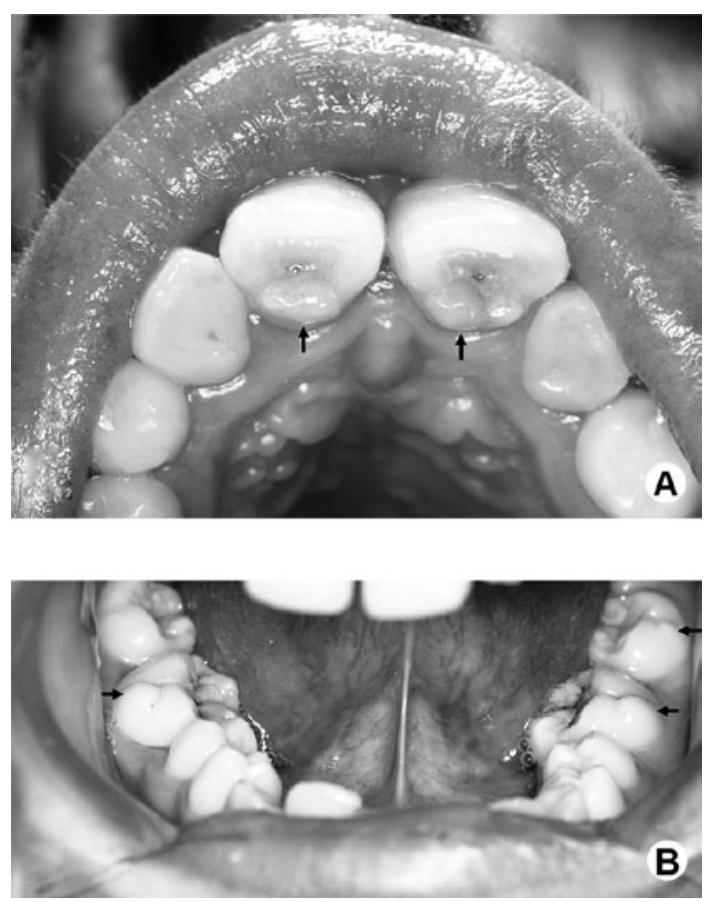

Figure 4. Intraoral clinical images. A: Prominent talon cusps on the maxillary central incisors. B: Talon cusps on the mandibular first molars and mandibular left second molar (Case 2).

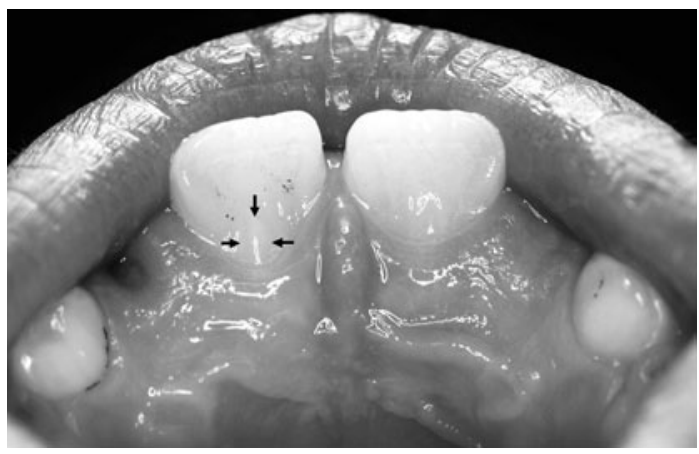

Figure 5. Intraoral clinical image. A trace talon cusp on the maxillary right central incisor. (Case 3). 
but these patients were carriers of Ellis-van Creveld and Berardinelli-Seip syndromes, respectively. Unlike these cases $(6,18)$, none of our patients presented talon cusp associated with any known systemic syndrome.

The talon cusp may cause clinical problems related to caries or occlusal interferences (7). Treatment objectives for talon cusps are aimed at the management of deep caries-susceptible pits and fissures, occlusal interferences, esthetic problems, soft tissue irritation, interference with the tongue space, and pulpal involvement (14). The treatment options for the mentioned problems are dependent upon the presence of a pulp horn in the cusp and include: placement of pit-and- fissure sealants or restorations, periodic gradual occlusal grinding, root canal therapy and extractions (1).

Mandibular talon cusps are less common than maxillary ones $(8,19)$. Talon cusp on the occlusal surface is subjected to direct occlusal forces, causing attrition or fracture at a much higher rate than the talon cusp on lingual surface (20). Early diagnosis and treatment of talon cusps is strongly recommended.

Due to the presence of a fistula in the open apex maxillary left central incisor, the first patient was referred for endodontic treatment of the tooth (root canal therapy with an apical MTA plug). Other teeth of this patient and the other cases underwent restorative and preventive therapies. Early oral examination could facilitate early diagnosis of the talon cusp and prevent occlusal problems and dental caries.

Based on this report and other similar anomalies in the family, it may be suggested that genetic inheritance may be a causative factor. However, genetic research needs to be carried out in order to prove this statement.

\section{RESUMO}

Cúspide em garra (talon cusp) é uma anomalia incomum, cuja etiologia pode estar relacionada a distúrbios no estágio de morfodiferenciação. Dens in dente é também uma anomalia rara que impõe desafios na prática clínica, uma vez que pode causar necrose pulpar ou lesões periapicais devido à comunicação com a cavidade oral. Este artigo relata múltiplos casos de cúspide em garra em incisivos e molares superiores e inferiores permanentes em 3 irmãos. Um menino de 9 anos apresentou-se com estruturas nodulares em formato de cone cilíndrico com uma ponta aguda ou de "gota de chuva", com fissuras de desenvolvimento profundas na face palatina dos incisivos centrais superiores, e face lingual dos incisivos centrais e vestibular de ambos os primeiros molares inferiores. A face vestibular do incisivo central superior esquerdo também foi afetada. Alguns dentes apresentavam dens in dente. Sua irmã de 15 anos apresentava cúspides em garra proeminentes na face palatina dos incisivos centrais superiores e face lingual dos primeiros molares inferiores e segundo molar inferior esquerdo. Seu irmão de 7 anos apresentava apenas uma cúspide em garra vestigial no incisivo central superior esquerdo. Nenhuma síndrome foi identificada nos pacientes. Conclui-se que a herança genética pode ser um fator causativo da cúspide em garra.

\section{REFERENCES}

1. Ekambaram M, Yiu CK, King NM. An unusual case of double teeth with facial and lingual talon cusps. Oral Surg Oral Med Oral Pathol Oral Radiol Endod 2008; 105:e63-e67.

2. Mitchell WH, Case report. Dental Cosmos 1892;34:1036.

3. Mellor JK, Ripa LW. Talon cusp: a clinically significant anomaly. Oral Surg Oral Med Oral Pathol 1970;29:225-228.

4. Hattab FN, Yassin OM, al Nimri KS. Talon cusp in permanent dentition associated with other dental anomalies: review of literature and reports of seven cases. ASDC J Dent Child 1996;63:368-376.

5. McNamara T, Haeussler AM, Keane J. Facial talon cusps. Int J Paediatr Dent 1997;7:259-262.

6. Solanki M, Patil SS, Baweja DK, Noorani H, PKS. Talon cusps, macrodontia, and aberrant tooth morphology in Berardinelli-Seip syndrome. Oral Surg Oral Med Oral Pathol Oral Radiol Endod 2008; 105:e41-e47.

7. Rayen R, Muthu MS, Sivakumar N. Aberrant talon cusps: report of two cases. J Indian Soc Pedod Prev Dent 2006;24:S7-S10.

8. Siraci E, Gungor HC, Cehreli ZC. Dens invaginatus and talon cusp co-occurring in a mandibular central incisor: a case report. J Dent Child 2008;75:177-180.

9. Gunduz K, Acikgoz A. An unusual case of talon cusp on a geminated tooth. Braz Dent J 2006;17:343-346.

10. Steffen H, Splieth C. Conventional treatment of dens invaginatus in maxillary lateral incisor with sinus tract: one year follow-up. $\mathrm{J}$ Endod 2005;31:130-133.

11. Tsurumachi T. Endodontic treatment of an invaginated maxillary lateral incisor with a periradicular lesion and a healthy pulp. Int Endod J 2004;37:717-723.

12. Stamfelj I, Kansky AA, Gaspersic D. Unusual variant of type 3 dens invaginatus in a maxillary canine: a rare case report. J Endod 2007;33:64-68.

13. Oehlers FA. Dens invaginatus (dilated composite odontome). I. Variations of the invagination process and associated anterior crown forms. Oral Surg Oral Med Oral Pathol 1957;10:1204-1218.

14. Yoon RK, Chussid S. Dental management of a talon cusp on a primary incisor. Pediatr Dent 2007;29:51-55.

15. Yeh SC, Lin YT, Lu SY. Dens invaginatus in the maxillary lateral incisor: treatment of 3 cases. Oral Surg Oral Med Oral Pathol Oral Radiol Endod 1999;87:628-631.

16. Meon R. Talon cusp in two siblings. N Z Dent J 1990;86:42-44.

17. Segura JJ, Jimenez-Rubio A. Talon cusp affecting permanent maxillary lateral incisors in 2 family members. Oral Surg Oral Med Oral Pathol Oral Radiol Endod 1999;88:90-92.

18. Hattab FN, Yassin OM, Sasa IS. Oral manifestations of Ellis-van Creveld syndrome: report of two siblings with unusual dental anomalies. J Clin Pediatr Dent 1998;22:159-165.

19. Danker E, Harari D, Rotstein I. Dens evaginatus of anterior teeth; literature and radiographic survey of 15,000 teeth. Oral Surg Oral Med Oral Pathol 1996;81:472-476.

20. Al-Omari MA, Hattab FN, Darwazeh AM, Dummer PM. Clinical problems associated with unusual cases of talon cusp. Int Endod J 1999;21:183-190. 